\title{
Cultural Transmission of National Dance under the "One Belt and One Road" Strategy
}

\author{
Xiaojie Wang ${ }^{1, \text { a }}$, Chi Zhang ${ }^{2, b}$ \\ ${ }^{1}$ College of Art and Communication, Bohai University, Jinzhou, 121013, China \\ ${ }^{2}$ School of Education and Sports, Bohai University, Jinzhou, 121013, China \\ a1019813588@qq.com, b378290420@qq.com
}

Keywords: One Belt And One Road; national dance; cultural transmission; cultural development; transmission countermeasures

\begin{abstract}
Natural dance is the communicate platform for people to build "One Belt And One Road", and helps the countries and regions along the "One Belt And One Road", actively participates in cultural exchange and cooperation, inherits the spirit of the Silk Road, promotes mutual understanding of civilizations and the "Going Global" of Chinese culture and expand the international influence of excellent national dance culture. This paper illustrates the strategy of "One Belt And One Road" and its cultural development. It analyzes the spread of national dance culture in the new media age and puts forward the countermeasures for the transmission of natural dance culture under the strategy of "One Belt And One Road". The specific measures include: set up a top-level design and build the harmonious national dance global perspective; rely on the strategic platform, in-depth the national culture and cultural exchanges; seize the strategic opportunities to expand the foreign national dance and cultural trade; tap the strategic heritage, promote outstanding national dance culture.
\end{abstract}

\section{Introduction}

The "One Belt And One Road" strategy truly reflects China, which is initiative to take up the challenge and strengthen the peaceful development of international exchanges in the new era. It is a major strategic plan that the Party Central Committee has taken to grasp the trend of globalization and coordinate the dual developmental environment at home and abroad. It has won the international help and support from many countries. The concept of "One Belt And One Road" not only strengthens the exchanges between the countries along the line, enhances the advantages and complements for each other, but also enables the eastern cultures to be transmitted to the extensive international world, so that the countries along the line can reach consensus on the era of solidarity and common development through the platform of cultural exchanges. The "One Belt And One Road" is not only an economic strategy or a diplomatic strategy for our country's opening economy to the outside world, but also an important cultural strategy for realizing the going out of Chinese culture.

The Chinese national dance is the general term for the traditional forms of dance with characteristics of all national minorities in China. It is formed by various minorities under long-term historical development under the different geographical environment, social life, customs, respective economic and cultural conditions. In the long history of our country, each nationality form the dance culture with unique national characteristics. The reason why the national dance culture is loved by the majority of the people is that people express their aspirations and their desire and pursuit for a better life so that they can enjoy physical and mental pleasure in the national dance culture. Under the strategy of "One Belt And One Road", it is necessary to inherit and carry forward the national dance culture so that it will be further carried out by the people. Cultural transmission of national dance must be strengthened so that excellent national dance culture can be shone in the exchange with the rest of the world. 


\section{2. "One Belt And One Road" Strategy and Cultural Development}

The history of the Silk Road, is not only the channel of economic and trade exchanges but also the road of cultural integration. It also represents the process of "Original Globalization" and carries the course of mutual learning between eastern and western civilizations. The Silk Road pioneered the original model of civilized exchange, shone in human history and provided the rich source for today's "One Belt And One Road" strategy. The "One Belt And One Road" strategy is not only an economic event that concerns the interests of all countries, but also the cultural event that resonates with the world. Respect the spiritual creation and cultural traditions of the people in the countries and regions along the "One Belt And One Road", take innovation as the driving force, make full use of internet thinking, new scientific and technological means to promote the in-depth integration of the multi-cultural "One Belt And One Road". Take into account the interests of all parties, follow international rules and market rules, give full play to the important role the market which plays in the allocation of resources, arouse the enthusiasm of all parties, closely integrate culture, diplomacy, economy and trade, and form the coordinated development of cultural exchange, cultural communication and cultural trade. Achieve mutual benefit and win-win situation. Specific cultural development action plans include:

(1) Improve the cultural exchange cooperation mechanism of "One Belt And One Road". Actively sign the intergovernmental documents with the countries and regions along the "One Belt And One Road", deepen cooperation mechanisms such as the Human Resources Cooperation Committee and the Cultural Commission, and provide effective protection for the development of the "One Belt And One Road" culture. We will promote the establishment of mechanisms for the exchange and cooperation of intangible cultural heritage with other countries and regions along the line. Establish long-term cooperation mechanisms with other countries and regions along the line to declare and protect cultural heritage and world heritage. Support the National Arts Fund and other countries and regions along the line with similar institutions to establish cooperation mechanisms.

(2) Improve the cultural exchange cooperation platform of "One Belt And One Road". We will give priority to promoting the construction of the Chinese cultural center in the countries and regions along the "One Belt And One Road" and improve the center layout of the countries and regions along the line. Strive to create an international exchange and cooperation platform featuring international arts festivals, expositions and art parks with the theme of "One Belt And One Road". Encourage and support all kinds of comprehensive international forums and fairs, and set up a cultural exchange section of "One Belt And One Road". Gradually establish the Silk Road cultural database to create the public digital culture support platform.

(3) Create the brand cultural exchange of "One Belt And One Road". Together with the countries and regions along "One Belt And One Road", we will jointly select "the cultural ambassador of Silk Road" and promote the exchange of ideas and culture through exchange and dialogue among the cultivation of think tanks, sinologists, translators and young talents. Prosper the "One Belt And One Road" theme culture arts production and advocate work with art talents and cultural institutions in countries and regions along the line to jointly create or promote the platform for display to enhance the professional standard and overall quality of art talent for the creation of Silk Road theme art talent resources.

(4) Promote the prosperity and development of the "One Belt And One Road" cultural industry. Improve the international cooperation mechanism for cultural industries and speed up the construction of the "Silk Road Cultural Industrial Belt" in the country. With cultural tourism, performing art entertainment, arts and crafts, creative design and digital culture as key areas, support areas along the "One Belt And One Road" in accordance with the regional characteristics and national characteristics and implement special cultural industry projects to strengthen cooperation with the "One Belt And One Road" countries in cultural resources digital protection and development cooperation, and actively use the "One Belt And One Road" cultural exchange and cooperation platform to promote cultural and creative products. 


\section{Artistic Characteristics of National Dance}

Dance is a kind of comprehensive art that combines many arts, including music, drama, painting and acrobatics. Chinese dance can be divided into classical dance and national folk dance. As one of the oldest forms of art, national folk dance is produced and circulated in the folk and deeply influenced by the folk culture. It is based on the majority of people and is collectively created, continuously accumulated, developed and inherited by the masses in the course of long history. Chinese is a multi-ethnic family. Due to the differences in living environment, living habits and aesthetic values, the Chinese national dance also has folkloric, regional and gendered characteristics. Sum up the artistic characteristics of national dance are reflected in the following aspects:

(1) Popularity. The national dance originates from the people, reflects the life, production and emotion with the simple and straightforward features and direct convenience. It is the crystallization of the labor and wisdom of the people for the masses of the people. Popularity is the value orientation of folk dance creation and the vitality of folk dance. Ignoring this aesthetic feature, without the most essential attributes of the masses of the people, it is impossible for the audience to affirm and like it. Therefore, it is necessary to capture the demeanor and charm of the people in the works, express their thoughts and emotions, generate the resonance of the prototype of life, and generate the emotion induction.

(2) Diversification. Chinese is a multi-ethnic family. The living environment, customs and beliefs, aesthetic ideals and aesthetic habits of all nationality are different, so that national dances also have their own characteristics. The rich and varied social life determines the diversity of national dance content as the artistic expression. China has the vast territory with large gap between north and south. Southern national dances show more tenderness and delicacy. Northern folk dances excel at masculine ruggedness. Diversify the national dance to absorb nutrition, create development, in the creation of dance to produce more different from other styles of dance.

(3) Openness. On the one hand, it absorbs other arts, especially foreign ideas and methods of creation and forms of expression; on the other hand, through various publicity media, it spreads the profound Chinese national dance to the world so that more people in all parts of the world understand the essence of Chinese national dance. Under the background of globalization, we will conduct research and practice aimed at the artistic development of Chinese national dance, such as the direction of development, dance movements, practical teaching and performance markets, attract top-notch talents in the field of creativity, performance and management, and solve practical problems with collective wisdom.

(4) Entertainment. As an art of expressing life, national dance has the function of spiritual education and entertainment of art. As a part of life, national dance has the practical function of life. Apart from some of the religious, war and ceremonial dance, most are free and lively, warm and straightforward. People in the spare time or festival festivals, with dance to express their happy mood, happy mood to meet entertainment and aesthetic requirements, and this character is closely related to the general character of the people themselves, to some extent, performance the people characters and aesthetic tastes.

\section{Cultural Transmission of National Dance in New Media Era}

Compared with traditional media, new media is a new form developed after traditional media such as newspapers, radio, television and so on. It uses digital technology, network technology, mobile technology and other channels such as internet, wireless communication network and wired network as well as computers, mobile phones, digital TVs and other terminals to provide users with information and entertainment forms of communication and media.

"New" of new media is reflected in the following: full range of digital, variety of information tools to participate, pictures, text, video can be released at the same time; interactivity, interactive real-time participation can be done; personality, everyone can become media publisher. With the development of technology, the forms of new media are more diversified, and the channels of 
communication are more extensive. Network technology also enables new media to be highly interactive, enabling real-time interaction across space and interactive time-to-comment. In addition, new media coverage is higher, accurate arrival, cost-effective. The promotion is even more ubiquitous, for example, wechat and other new media is the even more refreshing way. These characteristics occupy an increasingly important position in the modern media industry. These characteristics come from the progress of science and technology as well as the progress of science and technology. Changes in the ways in which new media disseminates content often result in changes in the context of communication and in the deconstruction and transformation of traditional discourse rights.

With the continuous expansion of the functions of new media technologies, the combination of national dance art and television has ushered in the marriage of ethnic dance art and the Internet. This is the application of traditional culture and art to modern new communication technologies, which not only expands the spread of national dance art Space, but also changed the existing form of national dance art. The national dance network communication also has the duality of this technology and art, which makes the network survival of ethnic dance art closely related to the development of Internet technology. The rapid rise of new media and huge space for development is the background of the spread of ethnic dance art. Since the new period, from the strategic height of national cultural development, the Party Central Committee has put forward the strategy of carrying forward national culture and revitalizing national art one after another and has provided strong support for the revitalization and development of national dance art. The new media has played an irreplaceable role in promoting popularization, enhancement, prosperity and development of ethnic dance art.

Web transmission content is still based on the stage performance. Through the network of highways, the majority of national dance art fans, you can easily approached the famous national dance art, into the outstanding works of national dance art, and thus to the broader national dance art world. The notable feature of internet communication is that the content is based on the electronic information and has greater degree of freedom than other modes of communication. Network communication not only gives the audience a great deal of freedom of choice, but also changes the relationship between the subject and the object, dissolves the right of discourse under the traditional mode of transmission, and enhances the audience's position in the communication process. It is a historic breakthrough.

\section{Countermeasures on Cultural Transmission of National Dance Under the "One Belt And One Road" Strategy}

Under the strategy of "One Belt And One Road", the national dance culture must rely on the support of the state policies and the layout of government agencies. It requires both deep-seated macro-level thinking, rational operation and scientific arrangements at the practical and operational levels. Specific measures are as follows:

(1) Based on the top-level design, construct the harmonious global perspective of national dance. Adhere to the strategic pattern of opening up to the outside world and give play to the government's lead and coordination role. We should step up cultural exchanges with countries and regions along the "One Belt And One Road" initiative and strive to establish the long-term cooperation mechanism that gives full play to the strengths of all parties and encourages active participation of social forces and common development. We should mobilize the enthusiasm of all parties and closely integrate culture with diplomacy and trade and economic cooperation to form the coordinated development of cultural exchange, cultural communication and cultural trade so as to achieve mutual benefits and win-win results. Explore the establishment of foreign dance culture industry fund, promote the effective allocation of cultural resources, rational flow of production factors, the depth of integration of cultural markets, the formation of the Silk Road national dance culture and rational development of the industrial layout.

(2) Rely on the strategic platform, carry out the national dance cultural exchange in depth. Strengthening exchanges and learning from different civilizations and promoting the common 
prosperity of multiple cultures are the trend of world cultural development as well as the cultural character of China. Under the "One Belt And One Road", China and other countries along the line carry out a wider range of activities such as cultural exchanges, academic exchanges, personnel cooperation and media interaction, laying the solid foundation of public opinions for deepening bilateral and multilateral cooperation. The strategy of "One Belt And One Road" has built the good platform for cultural exchanges along the line. National dance should make full use of this platform to conduct extensive publicity of national dance culture, organize national dance festivals, teach foreigners to learn national dance, and vigorously promote the development of national dance culture and foreign exchange.

(3) Seize the strategic opportunities and expand the foreign national cultural trade in dance. The "One Belt And One Road" has provided the brand new opportunity and rich subject for China to develop its cultural industry and further expand its foreign cultural trade. In the past, China's foreign trade in culture was mainly targeted at developed countries such as Europe, the United States, Japan and the Korea, and China possessed the serious trade deficit. The "One Belt And One Road" strategy has opened up the new world for China's cultural trade. It covers most of Central Asia, South Asia and most of Southeast Asia. Because of their geographical relationship, these regions have natural links with Chinese culture and are good partners for China's foreign cultural and trade cooperation in the future. The national dance culture should also seize this opportunity to form a batch of dance culture works with traditional characteristics and modernity.

(4) Excavate the strategic details and carry forward the excellent national dance culture. The "One Belt and One Road" strategy is an important measure to spread China's excellent traditional culture and shape the fine national image. Camel on the Silk Road, Zheng He's treasure ship under the West, brought out not only fine silk and porcelain, more splendid Chinese culture. The "Belt and Road" strategy itself is the wake-up call and the continuation of the fine traditional Chinese culture in the contemporary era. It is inseparable from carrying forward the traditional culture. The world will feel the Chinese traditional culture that is more solid, vivid, full of historical details and synchronized with the times. The national dance culture is an important part of Chinese traditional culture. As traditional Chinese culture developes hand in hand, it is bound to be promoted and developed in the "One Belt And One Road" strategy.

\section{Acknowledgement}

This work is supported by social science fund project of Liaoning province (L17CMZ002): Innovation measures on promote the outstanding national dance culture going out under the "One Belt And One Road" strategy.

\section{References}

[1] T. T. Dai, "Some thoughts on the inheritance and development of national dance culture," Modern Economic Information, vol. 22, no. 5, pp. 410-410, 2017.

[2] Y. Wang, "A survey of the current situation of Chinese national dance," Agriculture of Henan, vol. 27, no. 3, pp. 58-59, 2016.

[3] Y. M. Yang, "An Investigation Report on Dance Communication Approaches Based on Mass Media," Journal of Beijing Dance Academy, vol. 25, no. 1, pp. 86-92, 2011.

[4] P. Chen, "'One Belt And One Road': To explore ways of culture to go abroad," The world of humanity, vol. 4, no. 6, pp. 2-7, 2015.

[5] Y. A. Gao, "'One Belt And One Road' strategy to promote the Chinese traditional culture 'going out'," Business Culture, vol. 23, no. 11, pp. 51-57, 2016.

[6] J. Qin, H. B. Zhang, "'One Belt And One Road' is the national culture communication and identification in China." Journal of News Research, vol. 8, no. 9, pp. 6-8, 2017. 
[7] L. D. Chen, "On a Few Aspects of Cross- cultural Communication from the Perspective of 'One Belt And One Road'," Journal of Jiangxi Normal University (Philosophy and Social Sciences Edition), vol. 60, no. 1, pp. 69-73, 2016. 